\title{
Assessment of Rosa Majalis Herrm-Fruits Contamination with Heavy Metals in Open-Pit Coal Mine Waste Dumps
}

\author{
Irina Nikolaevna Egorova ${ }^{1,2}$, Olga Alexandrovna Neverova ${ }^{2} \&$ Lyubov Sergeevna Dyshlyuk $^{2}$ \\ ${ }^{1}$ Institute of Human Ecology SB RAS, Kemerovo, Russia \\ ${ }^{2}$ Kemerovo Institute of Food Science and Technology, Kemerovo, Russia \\ Correspondence: Olga Alexandrovna Neverova, Kemerovo Institute of Food Science and Technology, 47 \\ Stroiteley Boulevard, 650056 Kemerovo, Russia.
}

Received: July 19, $2014 \quad$ Accepted: October 14, $2014 \quad$ Online Published: March 11, 2015

doi:10.5539/mas.v9n4p270 URL: http://dx.doi.org/10.5539/mas.v9n4p270

\begin{abstract}
The work studies heavy metals content in embryo-earths and Rosa majalis Herrm. Fruits in conditions of "Kedrovsky" open-pit coal mine waste dump in Kuzbass region, Russia. It has been experimentally proven that embryo-earths of the dump are characterized by significant fluctuations in heavy metal content - maximum values are typical for $\mathrm{Mn}$ and $\mathrm{Fe}(79.5$ and $26.6 \mathrm{mg} / \mathrm{kg})$, minimum values for $\mathrm{Cd}$ and $\mathrm{Cu}(0.134 \mathrm{and} 0.27 \mathrm{mg} / \mathrm{kg})$. It has been found that the content of biologically active elements, $\mathrm{Cu}$ and $\mathrm{Zn}$, is below sufficient soils reserves. Comparison of results with hygienic standards did not reveal content of heavy metals in embryo-earths the dump more than MPC (APC). It has been found that the briar fruits accumulate more biophile metals ( $\mathrm{Mn}, \mathrm{Fe}, \mathrm{Zn}, \mathrm{Cu}$ ); content of technogenic group elements $(\mathrm{Pb}, \mathrm{Cd}, \mathrm{Cr}, \mathrm{Ni}, \mathrm{Co})$ is low - between 0.05 and $1.1 \mathrm{mg} / \mathrm{kg}$. Calculation of biological motility rate $(\mathrm{Bx})$ showed that briar fruits absorb more $\mathrm{Cu}(13.03)$ and $\mathrm{Zn}(4.82)$ from soil. For the majority of heavy metals $(\mathrm{Pb}, \mathrm{Cd}, \mathrm{Mn}, \mathrm{Ni}, \mathrm{Fe}$ and $\mathrm{Cr})$ inhibition of biological absorption $(\mathrm{Bx}<1)$ has been detected with minimum for $\mathrm{Pb}$. Hygienic assessment of Rosa majalis Herrm. fruits showed no excess in the content of heavy metals over MPC accepted for vegetative BAA, MPC based on generalized world information and regional background of ecologically pure areas of Kuzbass. The work accomplished proves safety of briar fruits grown at waste dumps of the Kedrovsky open-pit coal mine as far as ecotoxicants like heavy metals are concerned.
\end{abstract}

Keywords: open-pit coal mines, briar fruits, heavy metals, radionuclides

\section{Introduction}

Kuzbass is the center of the coal mining industry in Western Siberia. It has about 5 thousand industrial enterprises, including over 50 mines and open-pit coal mines. As a result of coal mining, the area of disturbed lands in the Kuzbass region exceeds 100 thousand hectares. In recent years about 20 thousand hectares have been rehabilitated, the rest of technogeneous land is subject to natural overgrowing due to drift of seeds from the surrounding areas.

At Kuzbass coal mines waste dumps, many medicinal herbs that are used in applied medicine grow, and local population collects and preserves them. However, wastes from coal production, i.e., dumps and terricones may be sources of high content of heavy metals.

HM hold a special place among the technogenic pollutants due to their wide occurrence and high toxicity. They are able to penetrate the biological cycle and cumulate in human body. In this regard, study of the resource potential of medicinal herbs growing at waste dumps of the Kuzbass coal mines and assessing their safety are actual.

Among brushwood at waste dumps of Kuzbass open-pit coal mines widespread is briar - Rosa majalis Herrm. of the Rose family (Rosaceae). Briar is a valuable forest improvement shrub and pharmacopoeial raw material that is used as a source of vitamins (State Register et al., 2008). Briar fruits contain ascorbic acid, carotenoids, flavonoids, catechins, carbohydrates, organic acids, vitamins B, K, P, E, polyunsaturated fatty acids, pectin, potassium, sodium, calcium, magnesium, phosphorus, iron, etc. (Andersson et al., 2012; Kumar et al., 2009; Zhang et al., 2013). Preparations made of briar fruits have a wide range of pharmacological action (Kirkeskov, et al., 2011; Muravyeva et al., 2002; Rein, et al., 2004; Schwager et al., 2011; Tumbas, et al., 2012; van der 
Westhuizen, et al., 2008), they are used in preparing combined nutritional food and drinks (Perfilova 2010; Volobueva and Kozlova, 2011; Vossen, et al., 2012).

To assess the possibility of using medicinal raw materials grown in the technologically altered areas in medicine and in food production, research of their hygienic safety is needed. Important health safety indicators of medicinal raw material include content of heavy metals (HM).

Currently, HM content in Medicinal Raw Herbs (MRH) is still not standardized in Russia, so many researchers for MRH hygienic assessment use indicators adopted for vegetative nutritional supplement (Gravelle et al., 2008). This work is a continuation of the previously published studies in hygienic assessment of medicinal herbs growing on dumps of the Kuzbass open-pit coal mines (Neverova and Egorova. 2013; Egorova and Neverova, 2013; Egorova and Neverova. 2013a).

Research in this area will make it possible to assess the possibility in principle of introduction and industrial harvesting of MRH on dumps of the Kuzbass open-pit coal mines, will expand the variety of MRH harvested in the region, as well as will introduce the lands disturbed by coal mining into commercial use.

The goal of this work is assessment of briar (Rosa majalis Herrm.) fruits and adjacent embryo-earths with heavy metals at "Kedrovsky" coal mine waste dump.

\section{Subject and Methods of Research}

The research was performed at the Yuzhny waste dump of the Kedrovsky open-pit coal mine. The total area of the "Yuzhny" waste dump is 599.3 hectares and it has the altitude of $58 \mathrm{~m}$, with plain-sloping terrain. Rocks that form dumps are mainly represented by sandstones $(60 \%)$ with a considerable shares of siltstone $(20 \%)$, and argillite (15\%), loam and clay (5\%).

Embryo-earths are mainly represented by heavy, moderately saturated clay loam (humus $3.5 \%$ ) characterized by alkaline reaction of soil solution ( $\mathrm{pH}$ of aqueous extract 7.1-7.7), low saturation with phosphorus and nitrogen (1.7-7.0) and content of exchangeable potassium little below normal $(125 \mathrm{mg} / \mathrm{kg})$. Objects of the study were samples of briar (Rosa majalis Herrm.) fruits and associated embryo-earths collected in years 2012 and 2013.

Raw material was procured during the period of full ripeness (early September), in dry sunny weather, according to the standard rules. The raw materials collected had no visible signs of damage. An average sample was prepared by quartering in accordance with GOST 24.027.0-80. Embryo-earths associated with the herbs were taken from the root layer $(\mathrm{A}$ 0-15 $\mathrm{cm})$ using usual methods.

Elemental analysis of embryo-earths samples and MRH was performed using the atomic absorption method in air-acetylene flame in spectrophotometer AAS - 30 from Karl Ceis Jena (Germany) on the basis of the accredited test center of the "Kemerovsky" agrochemical service. For extracting HM from soil, ammonium acetate buffer was used with $\mathrm{pH} 4.8$ in soil/solution ratio 1/10, time of extraction was 24 hours. Samples of plant raw materials were prepared by dry ashing followed by extraction with dilute nitric acid (1:1); time of extraction was 24 hours. To characterize availability of chemical elements for plants and extent of their use of mobile forms contained in embryo-earths, biological motility ratio (Bx) was calculated, i.e., the ratio of element concentration in the air-dry weight of the plant to the concentration of mobile forms of soil element. Analyses were performed in three replications; results were statistically processed using Statistica 6.0 software.

\section{Research Results}

Research results show that samples of dump embryo-earths are characterized by considerable fluctuations of elemental composition (Table 1). Maximum values are characterized by $\mathrm{Mn}$ and $\mathrm{Fe}$ (their contents 79.5 and $26.6 \mathrm{mg} / \mathrm{kg}$, respectively), minimum values for $\mathrm{Cd}$ and $\mathrm{Cu}(0.134$ and $0.27 \mathrm{mg} / \mathrm{kg}$, respectively). Low content level of dietary minerals was found, such as $\mathrm{Cu}$ and $\mathrm{Zn}$ - below soil sufficient saturation according to $\mathrm{N}$. K. Krupsky - G.N. Alexandrova. Comparison of HM content in dump embryo-earths with hygienic standards showed no excess of MPC (APC) (GN 2.1.7.2041-06; Chuldzhiyan et al., 1988) (Table 1). 
Table 1. HM content in embryo-earths and briar fruits at "Kedrovsky" coal mine waste dump

\begin{tabular}{ccccccc}
\hline Elements & \multicolumn{2}{c}{ Embryo-earths } & \multicolumn{3}{c}{ Content of elements, mg/kg } & \multicolumn{2}{c}{ Vegetative materials } & \\
& Mobile form & $\begin{array}{c}\text { MPC, APC } \\
*\end{array}$ & Briar fruits & RB* & $\begin{array}{c}\text { MPC for } \\
\text { BAA** }\end{array}$ & $\begin{array}{c}\text { MPC, world } \\
\text { generalized *** }\end{array}$ \\
\hline $\mathrm{Pb}$ & $2.183 \pm 0.037$ & 6.0 & $0.439 \pm 0.035$ & 1.18 & 6.0 & $5-10$ \\
$\mathrm{Cd}$ & $0.134 \pm 0.034$ & APC & $0.051 \pm 0.004$ & 0.21 & 1.0 & $0.05-0.2$ \\
$\mathrm{Cu}$ & $0.270 \pm 0.017$ & 3.0 & $3.517 \pm 0.230$ & 6.94 & - & $5-30$ \\
$\mathrm{Zn}$ & $0.990 \pm 0.053$ & 23.0 & $4.771 \pm 0.085$ & 9.96 & - & $27-150$ \\
$\mathrm{Mn}$ & $79.467 \pm 3.753$ & $140-500$ & $30.693 \pm 0.303$ & 21.58 & - & $20-300$ \\
$\mathrm{Ni}$ & $1.877 \pm 0.094$ & 4.0 & $1.100 \pm 0.047$ & 1.98 & - & - \\
$\mathrm{Co}$ & $0.757 \pm 0.072$ & 5.0 & $0.897 \pm 0.014$ & 2.15 & - & - \\
$\mathrm{Fe}$ & $26.060 \pm 0.552$ & - & $9.507 \pm 0.309$ & 104.51 & - & - \\
$\mathrm{Cr}$ & $1.277 \pm 0.054$ & 6.0 & $1.020 \pm 0.015$ & 4.08 & - & - \\
\hline
\end{tabular}

Notes: APC* is roughly allowable concentration. RF*- regional background - relatively clean zone (Egorova, 2010, Popov, 1995), MPC for BAA** (SanPin 2.3.2.1078-01. 2002), MPC, world generalized *** (Parkhomenko and Ermokhin, 2005).

It has been experimentally found that briar fruits accumulate more biophile metals - Mn (30.693mg/kg), Fe $(9.507 \mathrm{mg} / \mathrm{kg}), \mathrm{Zn}(4.771 \mathrm{mg} / \mathrm{kg})$ and $\mathrm{Cu}(3.517 \mathrm{mg} / \mathrm{kg})$. Content of technogenic group elements in briar fruits $(\mathrm{Pb}, \mathrm{Cd}, \mathrm{Cr}, \mathrm{Ni}, \mathrm{Co})$ is characterized by low values within $0.05-1.1 \mathrm{mg} / \mathrm{kg}$.

Calculations of biological motility coefficients (Bx) showed that briar fruits accumulate more $\mathrm{Cu}(13.03)$ and $\mathrm{Zn}$ (4.82) from soil. For the majority of heavy metals ( $\mathrm{Pb}, \mathrm{Cd}, \mathrm{Mn}, \mathrm{Ni}, \mathrm{Fe}$ and $\mathrm{Cr}$ ), inhibition of biological absorption $(\mathrm{Bx}<1)$ was detected with a minimum of $\mathrm{Pb}$ (Figure 1).

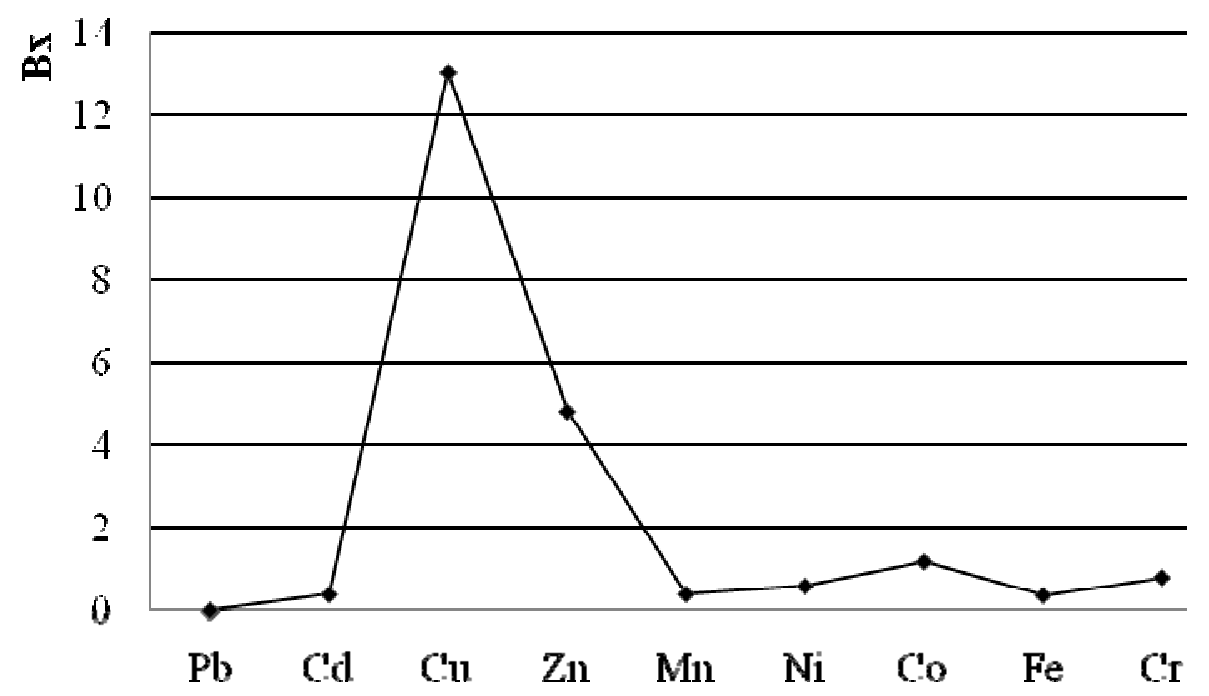

Figure 1. Biological motility coefficients (Bx) for Rosa majalis Herrm., growing at waste dumps

Inverse relationship has been found between the content of mobile forms of $\mathrm{Cu}$ and $\mathrm{Zn}$ in embryo-earths and the 
coefficients and their biological motility $(\mathrm{Bx})$-predominantly low values of mobile forms of these HMs in embryo-earths correspond to high indicators Bx (Table 1, Figure 1). This confirms existence of complex and apparently determined by plants' specie specificity mechanisms in plants for selective absorption and accumulation of chemical elements by various organs.

Hygienic assessment of Rosa majalis Herrm. fruits showed no excess in heavy metals content over the MPC accepted for vegetative BAA, MPC based on generalized world information and regional background of ecologically pure areas of Kuzbass.

\section{Discussion}

The fact of more substantial accumulation of biophile metals by briar fruits - $\mathrm{Mn}, \mathrm{Fe}, \mathrm{Zn}$ and $\mathrm{Cu}$ that we established is consistent with the results obtained by E.P. Pavlova (2009) who studied Rosa acicularis and R. Davurica fruits in the Republic of Buryatia and the Trans-Baikal region. This pattern was noted for fruits of other plants. In particular, M. Lavinia et al. (2012) established the regularity of biophile metal accumulation in fruits of Hippophae rhamnoides L. in the row: $\mathrm{Fe}>\mathrm{Mn}>\mathrm{Zn}>\mathrm{Cu}$; Ružica J. Micić et al. (2013) found higher contents of $\mathrm{Fe}, \mathrm{Zn}, \mathrm{Mn}, \mathrm{Cu}$ in fruits of red and white mulberry. Increased need for biophile metals in plants is obviously related to their participation in vital biochemical processes that determine normal growth and development.

Some researchers note that fruits of plants, unlike other morphological groups of raw materials (grass, leaves, flowers), accumulate heavy metals in much smaller quantities, and attribute this fact to the presence of scarfskin membrane of the fruits, from which in rainy season dust settled is washed away (Gravelle 2005; Strekalova, 2007). Peter Andráš et al. (2010) comparing certain types of plant tissues showed that the highest concentrations of heavy metals are found in roots, and the lowest - in flowers, seeds and fruits.

Literature states that concentration of heavy metals in plant fruits exceeds the maximum allowable safe level. In particular, Saeed Akhtar et al. (2010) in varieties of Pakistani mangoes found $\mathrm{Fe}, \mathrm{Zn}, \mathrm{Ni}, \mathrm{Cr}, \mathrm{Cd}, \mathrm{Pb}$ above safety limits set by the World Health Organization (WHO). Motylyova (2000), T.V. Sennovskaya (2004) recorded excess of maximum permissible concentration (MPC) of heavy metals in fruits and berries grown under increasing anthropogenic load. With that, contamination of fruits and berries can also be observed in cases where content of heavy metals in the soil is below MPC.

There is information that heavy metals accumulation depends on varietal characteristics of plants, in particular W. Letchamo et al. (2002) observed difference in the ability to accumulate heavy metals by buckthorn fruits depending on their variety. E.T. Egoshina (2008) notes that in technological areas of the Kirov region, accumulation of heavy metals above MPC by different parts of plants was observed. So, in fruits of R. majalis that grows in the mud lagoon of non-ferrous metals processing plant, lead content in fruits 7.8 times exceeds MPC. This author also notes that the process of lead accumulation in different organs of plants depends on particular species of plants. S.M.

\section{Conclusion}

The study established that embryo-earths of the dump are characterized by significant fluctuations in heavy metal content - maximum values are typical for $\mathrm{Mn}$ and $\mathrm{Fe}(79.5$ and $26.6 \mathrm{mg} / \mathrm{kg})$, minimum values for $\mathrm{Cd}$ and $\mathrm{Cu}(0.134$ and $0.27 \mathrm{mg} / \mathrm{kg})$. Content level of such dietary minerals as $\mathrm{Cu}$ and $\mathrm{Zn}$ was found below soil sufficient saturation according to N. K. Krupsky - G.N. Alexandrova. Comparison of HM content in dump embryo-earths to hygienic standards showed no excess of MPC (APC).

It has been found that the briar fruits accumulate more biophile metals - Mn (30.693 mg/kg), Fe (9.507 mg/kg), $\mathrm{Zn}(4.771 \mathrm{mg} / \mathrm{kg}), \mathrm{Cu}(3.517 \mathrm{mg} / \mathrm{kg})$; content of technogenic group elements $(\mathrm{Pb}, \mathrm{Cd}, \mathrm{Cr}, \mathrm{Ni}, \mathrm{Co})$ is low and ranges between 0.05 and $1.1 \mathrm{mg} / \mathrm{kg}$ with the minimum for $\mathrm{Cd}$ and the maximum for Ni. Calculations of biological mobility coefficients $(\mathrm{Bx})$ showed that briar fruits accumulate more $\mathrm{Cu}$ (13.03) and $\mathrm{Zn}$ (4.82) from soil. For the majority of heavy metals $(\mathrm{Pb}, \mathrm{Cd}, \mathrm{Mn}, \mathrm{Ni}, \mathrm{Fe}$ and $\mathrm{Cr})$ inhibition of biological absorption $(\mathrm{Bx}<1)$ has been detected with minimum for $\mathrm{Pb}$. Inverse relationship has been found between the content of mobile forms of $\mathrm{Cu}$ and $\mathrm{Zn}$ in embryo-earths and the coefficients and their biological motility (Bx) -predominantly low values of mobile forms of these HMs in embryo-earths correspond to high indicators Bx, which fact confirms the existence of the mechanism for separate adsorption of heavy metals in plants. Hygienic assessment of Rosa majalis Herrm. fruits showed no excess in the content of heavy metals over MPC accepted for vegetative BAA, MPC based on generalized world information and regional background of ecologically pure areas of Kuzbass.

So it has been experimentally proven that briar fruits grown at waste dump of the Kedrovsky open pit coal mine is ecologically safe as far as ecotoxicants like heavy metals are concerned. 


\section{References}

Akhtar, S., Naz, S., Sultan, M. T., Mahmood, S., Nasirand, M., \& Ahmad, A. (2010). Physico-Chemical Attributes and Heavy Metal Content of Mangoes (Mangifera Indica L.). Pakistan Journal of Botany, 42(4), 2691-2702.

Andersson, S. C., Olsson, M. E., Gustavsson, K. E., Johansson, E., \& Rumpunen, K. (2012). Tocopherols in rose hips (Rosa spp.) during ripening. Journal of the Science of Food and Agriculture, 92(10), $2116-21$. http://dx.doi.org/10.1002/jsfa.5594

Andráš, P., Lichý, A., Rusková, J., \& Matúšková, L. (2010). Heavy Metal Contamination of the Landscape at the L'ubietová Deposit (Slovakia). International Journal of Civil and Environmental Engineering, 2(2), 67-70.

Chuldzhiyan, H., \& Kirveta, S. et al. (1988). Heavy metals in soils and plants. Ecological Cooperation, 1, 5-24.

Egorova, I. N. (2010). Content of heavy metals and radionuclides in raw medicinal herbs of the Kemerovo region, thesis of Candidate of Biological Sciences, Tomsk, p: 21.

Egorova, I. N., \& Neverova, O. A. (2013). Analysis of Distribution of Radionuclides in Various Organs of Taraxacum officinale Web., which Grows in Rock Waste Disposal Areas of Coal Pits in Kuznetsk Basin. World Applied Sciences Journal, 24(3), 345-349.

Egorova, I. N., \& Neverova, O. A. (2013). Heavy Metal Concentration in the Herbal Medicinal Products of Hippophae Rhamnoides L., which Grows on Refuse Dumps of the Kuznetsk Coal Basin Surface Mines. World Applied Sciences Journal, 27 (Education, Law, Economics, Language and Communication): 497-500.

Egoshina, T. L. (2008). Influence of anthropogenic factors on the state of resources of wild fruit and medicinal herbs (on the example of the Kirov region), thesis of Dr. of Sciences, Perm, 44.

GN 2.1.7.2041-06. Maximum permissible concentration (MPC) of chemicals in soil: Hygienic standards, 2006. Moscow, 4.

Gravel, I. V. (2005). Regional problems of environmental assessment of MRH and herbal medicinal products on the example of the Altai Territory, PhD thesis, Moscow, 37.

Gravel, I. V., Petrov, N. V., \& Samilina, I. A. et al. (2008). Determination of heavy metals content in medicinal herbs. Pharmacy. GOST 24.027.0-80. Crude drugs. Acceptance rules and methods of sampling, 7, 3-5.

Kirkeskov, B., Christensen, R., Bügel, S., Bliddal, H., Danneskiold-Samsøe, B., Christensen, L. P., \& Andersen, J. R. (2011). The effects of rose hip (Rosa canina) on plasma antioxidative activity and C-reactive protein in patients with rheumatoid arthritis and normal controls: A prospective cohort study. Phytomedicine, 18(11), 953-958. http://dx.doi.org/10.1016/j.phymed.2011.02.008

Kumar, N., Bhandari, P., Singh, B., \& Bari, S. S. (2009). Antioxidant activity and ultra-performance LC-electrospray ionization-quadrupole time-of-flight mass spectrometry for phenolics-based fingerprinting of Rose species: Rosa damascena, Rosa bourboniana and Rosa brunonii. Food and Chemical Toxicology, 47(2), 361-367. http://dx.doi.org/10.1016/j.fct.2008.11.036

Letchamo, W., Klevakin, R., \& Lobatcheva, I. I. (2002). Heavy metal accumulation in sea buckthorn cultivars in Siberia. In Trends in New Crops and New Uses, Eds., Janick, J. and A. Whipkey. ASHS Press, Alexandria, VA., 399-401.

Micić, R. J., Dimitrijević, D. S., Kostić, D. A., Stojanović, G. S., Mitić, S. S., Mitić, M. N., Pavlović, A. N., \& Ranđelović, S. S. (2013). Content of Heavy Metals in Mulberry Fruits and Their Extracts-Correlation Analysis. American Journal of Analytical Chemistry, 4, 674-682. http://dx.doi.org/10.4236/ajac.2013.411081

Micu, L. M., Petanec, D., Imbrea, F., Pîrşan, P., \& Popovici, R. (2012). The influence of the chemical composition of tailings dumps on the mineral contents of sea buckthorn (Hippophae rhamnoides L.). Journal of Food, Agriculture \& Environment, 10(2), 1105-1109.

Motylyova, S. M. (2000). Particularities of $\mathrm{HM}$ content $(\mathrm{Pb}, \mathrm{Ni}, \mathrm{Zn}, \mathrm{Fe}, \mathrm{Cu})$ in fruits, berries and precipitation in relation to evaluation of varieties for breeding, thesis of Candidate of Biological Sciences, Orel, 17.

Muraveva, D. A., Samilina, I. A., \& Yakovlev, G. P. (2002). Pharmacognosy.Moscow: Medicine, 656.

Neverova, O. A., \& Egorova, I. N. (2013). Assessment of Heavy Metal Pollution of Medicinal Plants Taraxacum Officinale Web. Growing in the Kuznetsk Basin Areas Affected by Coal Production. World Applied 
Sciences Journal, 23(5), 650-655.

Parkhomenko, N. A., \& Ermokhin, Y. I. (2005). Agroekological assessment of heavy metals action in the soil-plant system along highways in the forest steppe of Western Siberia. Omsk, 110.

Pavlova, E. P. (2009). Influence of ecological and phytocoenotic factors on accumulation of biologically active substances in fruit of Rosa acicularis Lindley and Rosa daurica Pall. (Western Transbaikalia), thesis of Candidate of Biological Sciences, Ulan-Ude, 21.

Perfilova, A. O. (2010). New variety of bread with briar. Achievements of Science and Technology, 8, 77-78.

Popov, A. I. (1995). Study of the influence of anthropogenic factors on elemental composition and resources of medicinal plants of the Kemerovo region and the Republic of Tuva, thesis of PhD of Biological Sciences, Moscow, 460.

Rein, E., Kharazmi, A., \& Winther, K. A. (2004). Herbal remedy, Hyben Vital (stand. powder of a subspecies of Rosa canina fruits), reduces pain and improves general wellbeing in patients with osteoarthritis-a double-blind, placebo-controlled, randomized trial. Phytomedicine, 11(5), 383-391. http://dx.doi.org/10.1016/j.phymed.2004.01.001

Schwager, J., Hoeller, U., Wolfram, S., \& Richard, N. (2011). Rose hip and its constituent galactolipids confer cartilage protection by modulating cytokine, and chemokine expression. BMC Complementary and Alternative Medicine, 11, 105. http://dx.doi.org/10.1186/1472-6882-11-105

Sennovskaya, T. V. (2004). Factors of heavy metal accumulation in gooseberry berries and leaves. Fruit and berry breeding in Russia. Moscow, 281-295.

State Register of Medicinal Remedies. (2008). Vol.1, 2. Moscow: "Information and publishing agency "Remedium", 176.

State Standard of the Russian Federation. (2002). Food raw materials and food products. Hygienic safety requirements and nutritional value of food stuffs" of 2002 Volume SanPin 2.3.2.1078-01.

Strekalova, A. S. (2007). Substantiation of the technology for collecting medicinal plants in modern ecological situation (on the example of the Volgograd Region), thesis of Candidate of Biological Sciences, Volgograd, 21.

Tumbas, V. T., Canadanović-Brunet, J. M., Cetojević-Simin, D. D., Cetković, G. S., Ethilas, S. M., \& Gille, L. (2012). Effect of rosehip (Rosa canina L.) phytochemicals on stable free radicals and human cancer cells. Journal of the Science of Food and Agriculture, 92(6), $1273-81$. http://dx.doi.org/10.1186/1472-6882-11-105

van der Westhuizen, F. H., van Rensburg, C. S., Rautenbach, G. S., Marnewick, J. L., Loots, T. du, Huysamen, C., ... Erasmus, E. (2008). In vitro antioxidant, antimutagenic and genoprotective activity of Rosa roxburghii fruit extract. Phytotherapy Research, 22(3), 376-83. http://dx.doi.org/10.1002/ptr.2330

Volobuyeva, E. V., \& Kozlova, T. A. (2011). Development of formulations of meat products of functional and therapeutic purposes on the basis of wild briar fruit. Success of Contemporary Science, 7, 87-88.

Vossen, E., Utrera, M., De Smet, S., Morcuende, D., \& Estévez, M. (2012). Dog rose (Rosa canina L.) as a functional ingredient in porcine frankfurters without added sodium ascorbate and sodium nitrite. Meat Science, 92(4), 451-457. http://dx.doi.org/10.1016/j.meatsci.2012.05.010

Zhang, S., Qi, Y., Xu, Y., Han, X., Peng, J., Liu, K., \& Sun, C. K. (2013). Protective effect of flavonoid-rich extract from Rosa laevigata Michx on cerebral ischemia-reperfusion injury through suppression of apoptosis and inflammation. Neurochemistry International, 63(5), 522-532. http://dx.doi.org/10.1016/j.neuint.2013.08.008

\section{Copyrights}

Copyright for this article is retained by the author(s), with first publication rights granted to the journal.

This is an open-access article distributed under the terms and conditions of the Creative Commons Attribution license (http://creativecommons.org/licenses/by/3.0/). 